\title{
ASSESSMENT OF SELENIUM CONCENTRATION IN SELECTED ORGANS OF FARMED RACCOON DOGS (NYCTEREUTES PROCYONOIDES)*
}

\author{
Beata Seremak ${ }^{1}$, Bogumiła Pilarczyk ${ }^{1}$, Agnieszka Tomza-Marciniak ${ }^{1}$, \\ Renata Pilarczyk ${ }^{2}$, Andrzej Jakubczak ${ }^{3}$, Małgorzata Dziadosz', \\ Kamil Pławski ${ }^{1}$, Diana Hendzel ${ }^{1}$ \\ 'Department of Biotechnology of Animal Reproduction and Environment Hygiene, \\ ${ }^{2}$ Department of Ruminant Science, \\ West Pomerania University of Technology, Doktora Judyma 2-26, 71-466 Szczecin, Poland \\ ${ }^{3}$ Department of Biological Bases of Animal Production, University of Life Sciences in Lublin, \\ Akademicka 13, 20-950 Lublin, Poland \\ Corresponding author: beata.seremak@zut.edu.pl
}

\begin{abstract}
The aim of the study was to determine selenium concentrations in the liver, kidneys, lungs, heart and muscles of farmed raccoon dogs (Nyctereutes procyonoides) and to evaluate their impact on hair coat quality. Selenium concentration was determined using the modified Watkinson's spectrofluorometric method. Subjects were 20 farmed raccoon dogs (Nyctereutes procyonoides) at the age of 8-9 months, which were kept on a farm in south-eastern Poland. The results show that liver selenium content averaged $0.23 \pm 0.10 \mu \mathrm{g} / \mathrm{g}$ w.w. (wet weight). The concentrations ranged from 0.04 to $0.49 \mu \mathrm{g} / \mathrm{g}$ w.w. Kidney selenium concentration $(0.49 \pm 0.17 \mu \mathrm{g} / \mathrm{g}$ w.w. on average) was over twice that of liver concentration. Animals with higher scores for hair coat quality had lower selenium concentrations in the kidneys and liver, and higher selenium concentrations in muscles, but the differences were not significant. When relating Se concentrations determined in the liver of raccoon dogs to the biochemical criteria, it is concluded that $80 \%$ of the analysed raccoon dogs were deficient in this element and $20 \%$ had marginal levels. The results obtained in our study suggest that the food used on the farm did not fully meet the Se requirement of the raccoon dogs.
\end{abstract}

Key words: raccoon dogs, selenium, liver, kidneys, heart, lungs, muscles

Raccoon dogs are predators of the Canidae family which originate mainly from Asia and some regions of Europe. They are farmed for valuable fur which has long, dense and fluffy hairs. In Poland, raccoon dog farming began 30 years ago when the first animals were imported from Finland. In nature, raccoon dogs feed mainly on animal food, but their diet also contains plant foods such as young shoots, fruit and

*This study was financed by the National Centre for Research and Development, development project no. 12-0140-10. 
cereal seeds. The profitability of raccoon dog farming depends largely on well-balanced rations. Appropriate levels and ratios of macro- and micronutrients are essential to animal nutrition. One of the bioelements that determine the normal growth and health of animals is selenium.

In Poland and in the world, research on selenium concentration has focused on farm animals whose meat is used for food, namely cattle, sheep, pigs and horses (Hemingway, 2003; Ludvíková et al., 2005; Balicka-Ramisz et al., 2006; Pilarczyk et al., 2007, 2008, 2011a). On the other hand, few studies have investigated Se concentrations in fur animals (Tomza-Marciniak et al., 2010).

The biological function of selenium is attributed to its presence in glutathione peroxidase (GSHPx), the activity of which depends largely on selenium content (Pilarczyk et al., 2011b). The optimum concentration of selenium is a prerequisite for normal function of selenoproteins, which play a key role in many metabolic processes (Flohe, 1988). In animals, selenium has beneficial effects on reproduction and improves overall body condition and immunity, thus limiting the incidence of disease and having a positive effect on profitability of farming.

Dietary concentrations of selenium are strictly related to its soil levels (Zabłocki, 1990; Zust et al., 1996; Pilarczyk et al., 2010 b). Because the area of Poland is deficient in this element, animals are relatively often affected with Se deficiency.

In the Polish and foreign literature, few studies have investigated selenium concentrations in farmed raccoon dogs.

The aim of the study was to determine selenium concentrations in the liver, kidneys, lungs, heart and muscles of farmed raccoon dogs (Nyctereutes procyonoides) and to evaluate their impact on hair coat quality.

\section{Material and methods}

Subjects were 20 farmed raccoon dogs (Nyctereutes procyonoides) at the age of 8-9 months, which were kept on a farm in south-eastern Poland. The farm's environmental and hygienic conditions were found to be good. All animals were kept under the same environmental conditions in roofed outdoor cages made of wire. Their diet was formulated according to the nutrient requirements of this species (Barabasz et al., 1994). The basic components of the diet were poultry slaughter by-products $(50 \%)$ followed by beef by-products $(10 \%)$, MDM (Mechanically Deboned Meat) turkey meat $(5 \%)$, cod fish by-products $(5 \%)$, meat-and-bone meal $(2 \%)$, feather meal $(2 \%)$ and whole dried blood $(1 \%)$, preserved with $0.1 \%$ sodium pyrosulphate.

The rest of the diet contained cereal grains, sugar-beet pulp, and commercial vitamin-mineral premixes (GUYOFOX PLUS 0.1\%), which were supplemented according to the manufacturer's indications. Access to tap water was provided ad libitum.

When the fur was fully developed in October/November, the animals were subjected to pelt evaluation prior to slaughter. One of the components of this evaluation is hair coat quality, which is scored on a scale of 1 to 8 . The animals were divided accordingly into group $\mathrm{A}$ ( $\geq 6$ points) and group $\mathrm{B}$ ( $\leq 5$ points). The following parameters were used when evaluating hair coat quality: density of guard hair and under- 
fur, uniformity of hair density over entire trunk, length of guard hair and underfur, difference in hair coat height between the back and abdomen, and hair silkiness and resilience.

Samples of liver, kidneys, heart, lungs and thigh muscle were analysed for selenium content. The tissue samples, obtained at slaughter and pelting time (end of November) were put into polyethylene bags and kept frozen at $-20^{\circ} \mathrm{C}$ until analysed. Selenium concentrations were determined spectrofluorometrically with the method of Watkinson (1966), modified by Grzebuła and Witkowski (1977). The samples of organs $(0.5-1.5 \mathrm{~g})$ were wet mineralized in concentrated $\mathrm{HNO}_{3}\left(230^{\circ} \mathrm{C} / 180 \mathrm{~min}\right)$ and $\mathrm{HClO}_{4}\left(310^{\circ} \mathrm{C} / 20 \mathrm{~min}\right)$. Mineralized samples were hydrolyzed with $9 \% \mathrm{HCl}$ to reduce selenates (Se VI) to selenites (Se IV). Selenites were then complexed with 2,3-diaminonaphthalene (Sigma) and the complex obtained was extracted with cyclohexane (Chempur). Fluorescence was measured in the organic (cyclohexane) layer using an emission wavelength of $518 \mathrm{~nm}$ and an excitation wavelength of $378 \mathrm{~nm}$. The accuracy of the analytical method was determined based on reference material (BCR-185R bovine liver, European Commission Joint Research Centre Institute for Reference Materials and Measurements, LGC Standards GmbH, Germany).

Statistical calculations were performed using procedures of Statistica PL 7.1. All data are expressed throughout as an arithmetic mean \pm SD and also geometric mean. The concentrations of Se were log-transformed to attain or approach a normal distribution of the data. The effect of sex, weight, body length and pelt evaluation on Se concentration in the liver, kidneys, heart, lungs and muscle was analysed using generalized linear models (GLM). Differences were considered as significant at the level of $\mathrm{P} \leq 0.05$. Relationships between concentrations of selenium in the liver, kidneys, heart, lungs and muscle were evaluated by calculating Pearson's correlation coefficient (rx,y). Statistical significance of the correlation coefficients was tested at the level of $\mathrm{P} \leq 0.05$.

\section{Results}

Data on selenium concentration in the kidneys, liver, lungs, heart and muscles of raccoon dogs are given in Table 1. The results show that liver selenium content averaged $0.23 \pm 0.10 \mu \mathrm{g} / \mathrm{g} \mathrm{w}$.w. (wet weight). The concentrations ranged from 0.04 to $0.49 \mu \mathrm{g} / \mathrm{g}$ w.w. Kidney selenium concentration $(0.49 \pm 0.17 \mu \mathrm{g} / \mathrm{g}$ w.w. on average $)$ was over twice that of liver concentration. At the same time, lung Se concentration $(0.14 \pm 0.04 \mu \mathrm{g} / \mathrm{g} \mathrm{w} . \mathrm{w})$ was over four times as low as in kidneys. The data also show that selenium concentration averaged $0.10 \pm 0.03 \mu \mathrm{g} / \mathrm{g} \mathrm{w} . \mathrm{w}$. in the heart and $0.08 \pm 0.04 \mu \mathrm{g} / \mathrm{g} \mathrm{w} . \mathrm{w}$. in muscles.

The mean selenium concentration in cardiac muscle was significantly $(\mathrm{P} \leq 0.05)$ higher in females than in males. Higher selenium concentrations were also found in the liver of females and in the kidneys of males, with no significant differences. Mean selenium concentrations in the kidneys and liver were higher in raccoon dogs weighing up to $11 \mathrm{~kg}$ compared to animals weighing over $11 \mathrm{~kg}$, while the mean concentration of selenium in the other organs was similar. 


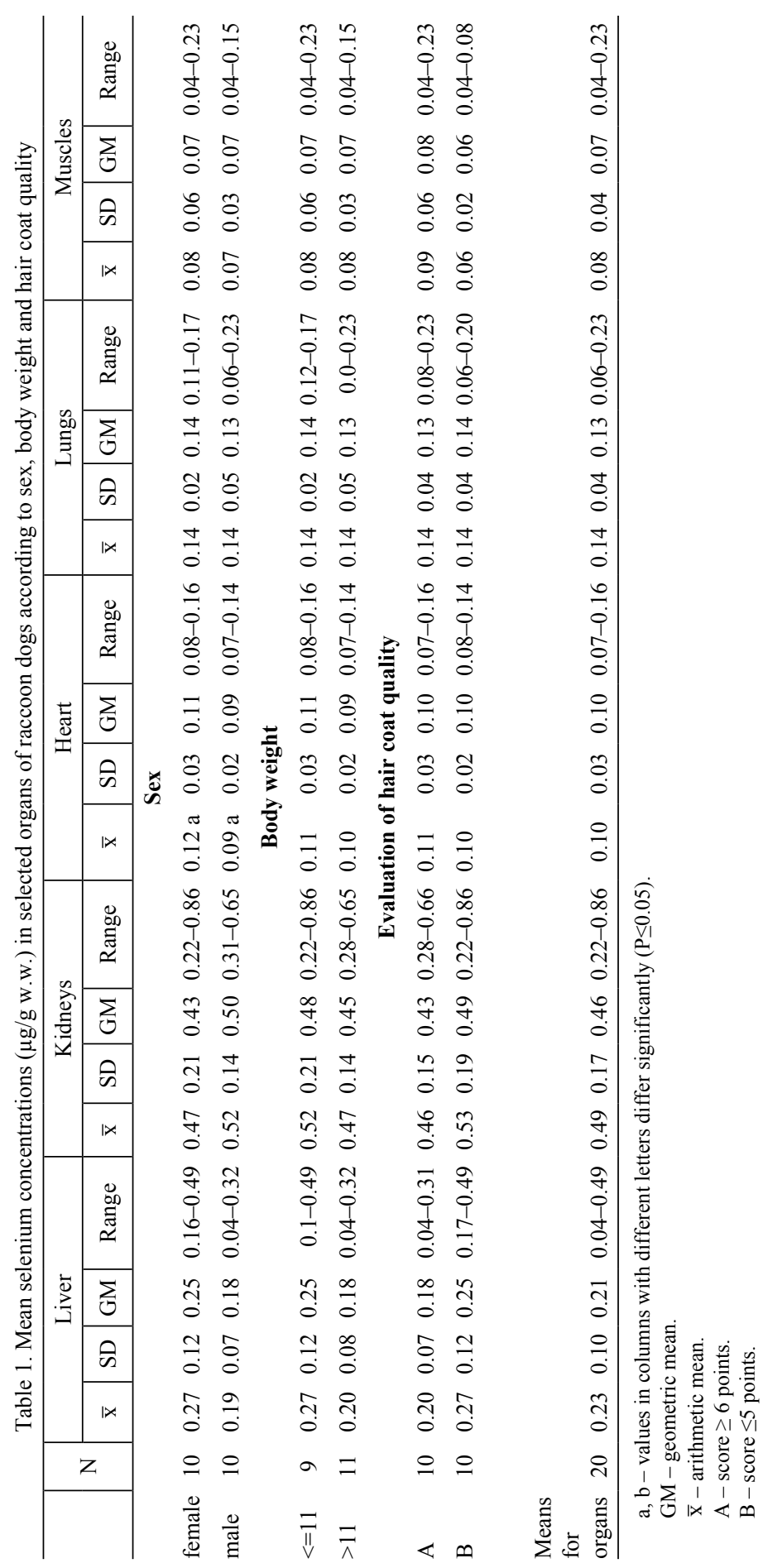




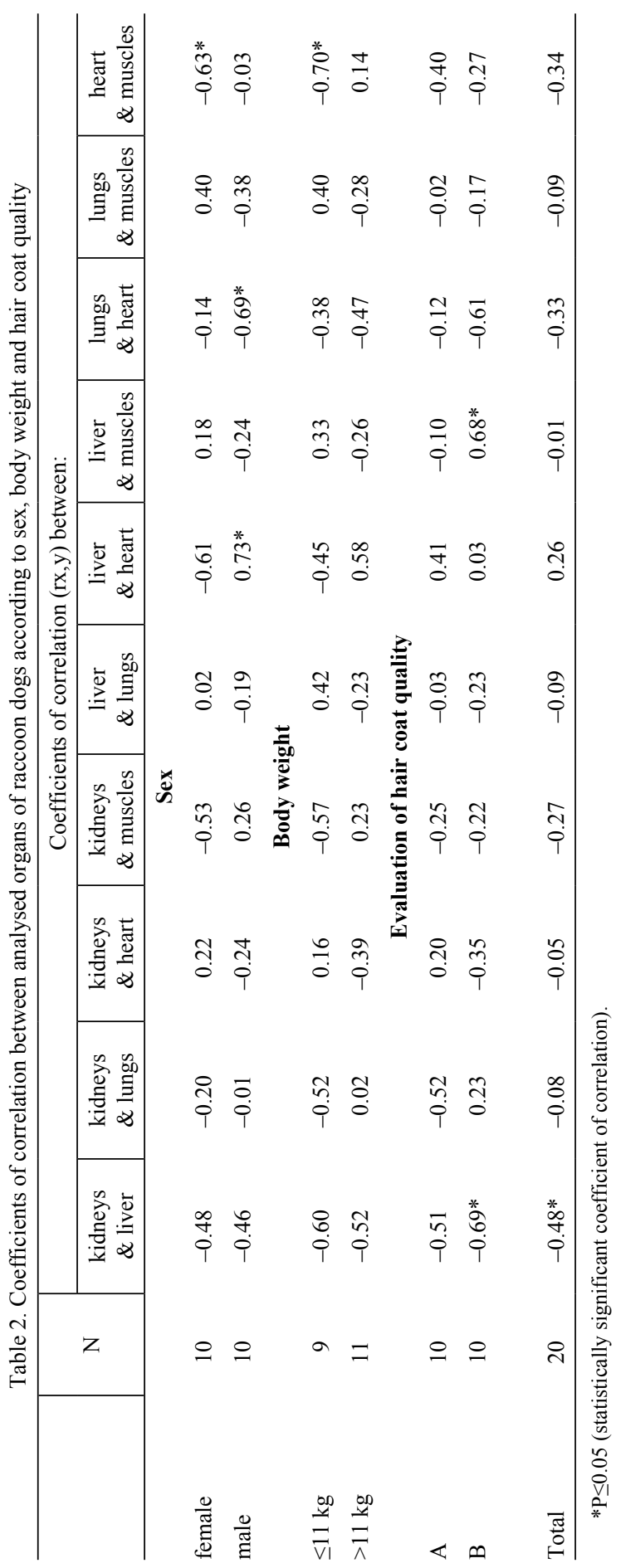


Animals with higher scores for hair coat quality (A) had lower selenium concentrations in the kidneys and liver, and higher selenium concentrations in muscles, but the differences were not significant.

The coefficients of correlation within selected organs of raccoon dogs are shown according to sex, body weight, body length and pelt evaluation in Table 2 . When analysing the relationship between selenium concentrations in different organs, a statistically significant $(\mathrm{P} \leq 0.05)$ correlation was only found between selenium concentrations in the kidneys and liver $(\mathrm{r}=-0.48)$ of all raccoon dogs investigated.

Detailed analysis revealed highly significant $(\mathrm{P} \leq 0.05)$ correlations in males between liver and heart $(\mathrm{r}=0.73)$ and lung and heart selenium concentrations $(\mathrm{r}=-0.69)$; in females between heart and muscle selenium concentrations $(\mathrm{r}=-0.63)$; in animals weighing up to $11 \mathrm{~kg}$ between heart and muscle selenium concentrations $(\mathrm{r}=-0.70)$; and in animals with lower scores for hair coat $(\mathrm{B})$ between liver and kidney $(r=-0.69)$ and liver and muscle selenium concentrations $(r=0.68)$.

\section{Discussion}

Selenium absorption is not regulated by metabolic processes, but the amount of absorbed selenium depends on its chemical form and dietary concentration (Whanger, 1994). Raccoon dogs can absorb selenium from food in the form of inorganic compounds such as selenites $\left(\mathrm{Me}_{2} \mathrm{SeO}_{3}\right)$ or selenates $\left(\mathrm{Me}_{2} \mathrm{SeO}_{4}\right)$ and organic compounds such as selenomethionine (SeMet) and selenocysteine (SeCys). The amount of intestinally absorbed selenium is in the $85-95 \%$ range. Selenium is best absorbed from organic compounds (90-95\%) and its bioavailability from inorganic compounds is about 10\% lower (Zaporowska, 2002).

Selenium deficiency in Polish soils is the reason for its low content in plants, resulting in the low selenium content of food (Pilarczyk et al., $2010 \mathrm{a}, \mathrm{b}$ ).

Because there are no literature data concerning Se concentrations in the organs of raccoon dogs, the present findings were related to the data obtained for other canids. Selenium concentrations determined in raccoon dog organs in the present study were lower than the values found in the tissues of farmed foxes by Balicka-Ramisz et al. (2010), who observed mean selenium concentration in foxes to be $0.243 \mu \mathrm{g} / \mathrm{g} \mathrm{w}$.w. in the liver and $0.591 \mu \mathrm{g} / \mathrm{g} \mathrm{w} . \mathrm{w}$. in kidneys. Hoekstra et al. (2003) and Prestrud et al. (1994) found higher selenium concentrations $(0.75 \mu \mathrm{g} / \mathrm{g}$ w.w. $)$ in the liver of freeliving compared to farmed foxes.

In our study, kidneys had the highest selenium concentration of all organs, with several-fold lower concentrations found in the liver, lungs and heart.

Puls (1994) reported the following biochemical criteria for diagnosing selenium deficiency in the liver of Canidae: below $0.3 \mu \mathrm{g} / \mathrm{g}$ w.w. - deficiency; $0.3-0.5 \mu \mathrm{g} / \mathrm{g}$ w.w. - marginal level; 0.5-1.5 $\mu \mathrm{g} / \mathrm{g} \mathrm{w}$.w. - appropriate (optimal) level for this group of animals. When relating Se concentrations determined in the liver of raccoon dogs to the biochemical criteria, it is concluded that $80 \%$ of the analysed raccoon dogs were deficient in this element and $20 \%$ had marginal levels. None of the analysed 
raccoon dogs had optimum Se concentrations. A similar situation occurred for kidneys, where selenium concentration in canids should range from 1.0 to $1.5 \mu \mathrm{g} / \mathrm{g} \mathrm{w} . \mathrm{w}$. (Puls, 1994).

Kidney selenium content helps in diagnosis of selenium deficiency in animals. Oh et al. (1976) observed selenium concentrations in animals on selenium-deficient feeds to be much higher in kidneys than in the liver. A reverse situation occurred for animals fed selenium-rich feeds. In our study, we observed selenium concentrations in the livers of raccoon dogs to be over two-fold lower than in the kidneys, possibly indicating that their diets were too low in this element or Se was present in a poorly available form.

The low selenium concentration in the body reduces its content in all organs, which may impair their function. The mean Se concentrations obtained in our study in the heart and lungs were 0.10 and $0.14 \mu \mathrm{g} / \mathrm{g} \mathrm{w}$.w., respectively. Because liver and kidney concentrations of Se were found to be low, its concentration in the heart is also considered inadequate. This may result in the dysfunction of this organ. Normal heart work is conditional on selenium, which is found in the enzyme that controls the formation of muscle protein (cardiac muscle protein). Selenium deficiency in humans causes cardiomyopathy (Keshan disease) endemic to some parts of China (Rayman, 2000). The heart condition resembles the mulberry heart disease (MHD), which is found in cattle. It is characterized by degenerative changes in the heart muscle, resulting in anomalous blood circulation in the body. Yegin et al. (1997) and Altekin et al. (2005) showed an inverse relationship between increased atherosclerotic lesions in coronary vessels and low selenium concentration in the blood and in the environment.

Yu et al. (2006) reported a positive effect of a diet with adequate selenium content on the growth rate of dogs and quality of their hair. These authors demonstrated that appropriate selenium concentrations in dog food considerably improve hair quality in dogs, but our study failed to confirm this relationship.

The results obtained in our study suggest that the food used on the farm did not fully meet the Se requirement of the raccoon dogs. We attribute such low Se concentrations to the inadequate content of the available form of this element in the standard food for raccoon dogs. For this reason, it is necessary to check selenium concentrations in the body of raccoon dogs and in their feed. A proper prophylactic programme should be applied in case of deficiency.

\section{References}

Altekin E., Coker C., S is man A.R, Onvural B., Kuralay F., Kirimli O. (2005). The relationship between trace elements and cardiac markers in acute coronary syndromes. J. Trace Elem. Med. Biol., 18: 235-242.

Balicka-Ramisz A., Pilarczyk B., Ramisz A., Pilarczyk R., Nader K. (2010). Selenium concentrations in the liver, kidneys, and muscles in silver foxes (Vulpes vulpes). Bull. Vet. Inst. Pulawy, 54: 265-267.

B a li cka - R a m is z A., P i larczyk B., R a m is z A., W i e c zor ek - D ąbrow ska M. (2006). Effects of selenium administration on blood serum Se content and on selected reproductive characteristics of sheep. Arch. Tierzucht, 2: 176-180. 
B arabasz B., Bielański P., Jarosz S., Niedźwiadek S., Sław oń J. (1994). Feeding standards for carnivorous and herbivorous fur animals - nutritive value of feeds. Published by J. Kielanowski Institute of Animal Physiology and Nutrition, Jabłonna, pp. 30-36.

F lo he L. (1988). Glutathione peroxidase. Basic Life Sci., 49: 663-668.

Grze buła S., W it k ow s ki P. (1977). Bestimmung der Selenspurenanzahl im biologischen Material mit fluorimetrischer Methode. Teil I. Bestimmung von Selen in Geweben und örperflüssigkeiten. Pol. Arch. Wet., 20: 125-138.

H e m in g w a y R.G. (2003). The influences of dietary intakes and supplementation with selenium and vitamin $\mathrm{E}$ on reproduction diseases and reproductive efficiency in cattle and sheep. Vet. Res. Commun., 27 (2):159-74.

Hoekstra P., Braune B.M, Elkin B., Armstrong F.A, Muir D.C. (2003). Concentrations of selected essential and non-essential elements in arctic fox (Alopex lagopus) and wolverines (Gulo gulo) from the Canadian Arctic. Sci. Total Environ., 309 (1-3): 81-92.

Ludvíková E., Jahn P., Pavlata L., Vyskočil M. (2005). Selenium and vitamin E status correlated with myopathies of horses reared in farms in the Czech Republic. Acta Vet. Brno, 74 (3): 377-384.

Oh S.H., Sunde R.A., Pope A.L., Hoekstra W.C. (1976). Glutathione peroxidase response to selenium intake in lambs fed a Torula yeast-based, artificial milk. J. Anim. Sci., 42: 977-983.

Pilarczyk B., Balicka-Ramisz A., Ramisz A., Vovk S., Krużel B., Tomza A. (2007). Selengehalte im Blutserum von Kühen, Schafen und Schweinen in der Westukraine und Westpommern. Tierärztl. Umschau, 62: 123-126.

Pilarczyk B., B a li cka-Ramisz A., Ramisz A., Pilarczyk R., Sablik P., Wójcik J. (2008). Selengehalte im Blutserum von aus Deutschland, Tschechien, Frankreich und Holland nach Polen importierten Rindern. Tierärztl. Umschau, 63: 243-246.

Pilarczyk B., Hendzel D., Pilarczyk R., Tomza-Marciniak A., Błaszczyk B., Dąbrowska-Wieczorek M., Bąkowska M., A damowicz E., Bujak T. (2010 a). Liver and kidney concentrations of selenium in wild boars (Sus scrofa) from northwestern Poland. Eur. J. Wildl. Res., 56 (5): 797-802.

Pilarczyk B., Tomza-Marciniak A., Mituniewicz-Małek A., Wieczorek M., Pila r c zy k R., Wój c i k J., B a li c k a - R a mis z A., B ą k ow s k a M., D m y trów I. (2010 b). Selenium content in selected products of animal origin and estimation of the degree of cover daily Se requirement in Poland. Int. J. Food Sci. Tech., 45: 186-191.

Pilarczyk B., Udała J., S tankiewicz T., Hendzel D., Tylkowska A. (2011 a). Beurteilung der Selengehalte im Blutserum von Pferden in Polen. Tierärztl. Umschau, 66: 163-165.

Pilarczyk B., Drozd R., P i larczyk R., Tomza-Marciniak A., Jankowiak D., Hend z e 1 D., K u b a J., K o w a 1 s k a J. (2011 b). Glutathione peroxidase (GSHPx) activity in the liver of red deer in relation to hepatic selenium concentrations, sex, body weight and season of the year. Biol. Trace Elem. Res. DOI 10.1007/s12011-011-9022-0.

Prestrud P., N orheim G., S i verts e n T., D a a e H.L. (1994). Levels of toxic and essential elements in arctic fox in Svalbard. Polar Biol., 14: 155-159.

Puls R. (1994). Mineral levels in animal health: diagnostic data, 2nd ed. Sherpa International, Clearbrook, British Columbia, p. 356.

R a y m a n M. (2000). The importance of selenium to human health. Lancet, 356: 233-241.

Tomza-Marciniak A., Seremak B., Bąkowska M., Nadzieja K., Tylkowska A. (2010). Assessment of selenium (Se) concentration in selected organs of ranch mink (Mustela vison). Acta Sci. Pol., Zootechnica, 9 (1): 41-46.

W a t k in s on J.H. (1966). Fluorometric determination of selenium in biological material with 2,3 diaminonaphthalene. Anal. Chem., 38: 92-103.

Whanger P.D., Xi a Y., Thom son C.D. (1994). Protein techniques for selenium speciation in human body fluids. J. Trace Elem. Elect. Health Dis., 8: 1-7.

Yegin A., Yegin H., Aliciguzel Y., Deger N., S e miz E. (1997). Erythrocyte seleniumglutathione peroxidase activity is lower in patients with coronary atherosclerosis. Jpn. Heart J., 38 : 793-798.

Y u S., W e de kin d K.J., K irk C.A., N a c hre in e r R.F. (2006). Primary hair growth in dogs depends on dietary selenium concentrations. J. Anim. Physiol. An. N., 90: 146-151. 
Z a b ł o c k i Z. (1990). Selenium in the soils and plants of West Pomerania. (In Polish). Dissertation No. 21, Agricultural University, Szczecin, Poland.

Z a p o r ow sk a H. (2002). Micronutrients in animal and human life. (In Polish). Wyd. UMCS Lublin. $\mathrm{Zu}$ s t J., H rovat in B., S i m undic B. (1996). Assessment of selenium and vitamin E deficiencies in dairy herds and clinical disease in calves. Vet Rec., (16): 391-394.

Accepted for printing 17 VIII 2011

\section{BEATA SEREMAK, BOGUMIŁA PILARCZYK, AGNIESZKA TOMZA-MARCINIAK, RENATA PILARCZYK, ANDRZEJ JAKUBCZAK, MAŁGORZATA DZIADOSZ, KAMIL PŁAWSKI, DIANA HENDZEL}

\section{Ocena stężenia selenu w wybranych narządach jenotów hodowlanych (Nyctereutes procyonoides)}

\section{STRESZCZENIE}

Celem pracy było określenie stężenia selenu w wątrobie, nerkach, płucach, sercu oraz mięśniach jenotów hodowlanych (Nyctereutes procyonoides) oraz ocena jego wpływu na jakość pozyskiwanych skór. Stężenie selenu oznaczano zmodyfikowaną metodą spektrofluorymetryczną Watkinsona. Materiał badawczy stanowiło 20 jenotów hodowlanych (Nyctereutes procyonoides) w wieku 8-9 miesięcy, utrzymywanych na fermie w Polsce południowo-wschodniej. Z uzyskanych danych wynika, że średnia zawartość selenu w wątrobie jenotów wyniosła $0,23 \pm 0,10 \mu \mathrm{g} / \mathrm{g}$ m.m. (mokrej masy). Odnotowane koncentracje wahały się w zakresie od 0,04 do $0,49 \mu \mathrm{g} / \mathrm{g} \mathrm{m} . \mathrm{m}$. W wątrobie odnotowano ponad dwukrotnie niższą zawartość selenu niż w nerkach, średnio w nerkach $0,49 \pm 0,17 \mu \mathrm{g} / \mathrm{g} \mathrm{m} . \mathrm{m}$. Osobniki, które otrzymały wyższą ocenę jakości okrywy włosowej charakteryzowały się niższym stężeniem selenu w nerkach i wątrobie, natomiast wyższym w mięśniach. Różnice te nie były jednak statystycznie istotne. Odnosząc oznaczone koncentracje Se w wątrobie jenotów do biochemicznych kryteriów należy stwierdzić, że u $80 \%$ badanych jenotów hodowlanych występuje niedobór tego pierwiastka, u $20 \%$ poziom marginalny. Uzyskane wyniki mogą sugerować, że stosowana na fermie karma nie pokrywała w pełni zapotrzebowania jenotów na selen. 